\title{
Demand for DNA probe testing in three genetic centres in Britain (August 1986 to July 1987)
}

R J RONA, A V SWAN, R BEECH, L PRENTICE, A REYNOLDS, O WILSON, G MOLE, AND P VADERA

From the Division of Community Health, United Medical and Dental Schools of Guy's and St Thomas's Hospitals, St Thomas's Campus, London SE1 7EH.

SUMMARY We report a preliminary analysis of the data collected during the first year of the $\tilde{\sigma}_{\sigma}$ evaluation of clinical genetics in the context of DNA probes in three genetic centres, to show the pattern of the demand for genetic services in the three centres and the services used in meeting $N$ that demand.

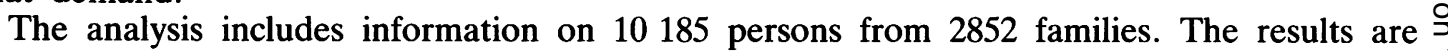
presented according to mode of inheritance and according to the most common disorders for $\vec{\rightarrow}$ which DNA probes have been used in the three centres.

The results indicate that the use of DNA probes is now a major element of activity in genetic departments, and that as long as indirect DNA probe testing is the predominant manner of using recombinant technology, the clinical input will be an important element of the costs, probably more so than that of the DNA laboratories, as a large number of family members needs to be tested.

In most cases centres have concentrated activity on DNA testing for common and severe genetic disorders. However, there are disorders, such as familial hypercholesterolaemia, which have not been part of the established pattern of services. Conversely, a relatively high number of families have been studied for some disorders of very low incidence. This suggests that the number of DNA laboratories should be limited. The precise arrangements will need to be established. With such services the distribution of DNA testing facilities for different disorders can be controlled to limit duplication. The model followed in Scotland based on collaboration between centres is worth considering.

We have detected very large differences in take up rate of services within and between regions. Although many factors may contribute to these differences, ease of access and lay and professional awareness are probably the most important. This is supported by the fact that more patients from the same or neighbouring DHAs attend the genetic centre than from those further away. We also concluded that published guidelines for clinicians in general on the uses of DNA probes, the type of families that could benefit, and the centres to which referrals should be sent would be very useful in increasing coverage and maximising the effectiveness of the services. Since this may increase demand, this educative tool should be coordinated and agreed by the Departments of Health with all the genetic departments and centres in the country.

The use of DNA probe testing for several single gene disorders has been increasing since this development was first reported in 1978. The Departments of Health allocated funds to three genetic centres in Manchester, Cardiff, and the Institute of Child Health in London as a Special Medical Development (SMD) project for three years to develop recombinant DNA technology to the stage

Received for publication 11 November 1988.

Accepted for publication 1 December 1988. where it can be applied routinely in the National Health Service (NHS). An evaluation of this process has been taking place since August 1986, after a pilot study to develop methodology for data collection. The ultimate aim of the study is to provide an overview of the effectiveness of DNA probe testing. This paper is a preliminary report, based on the first year's collection of data, on the characteristics of the current service demand.

Genetic service activity is currently affected by a 
backlog of work arising from families who were known to the centres but who have only recently been assessed using DNA probes, patients referred from other regions, and a number of patients with diseases that, for historical reasons, were not previously referred to the genetic centres.

In this report we are particularly interested in describing the disorders for which DNA probe testing has been developed and their severity, how the amount of contact with family members varies according to the mode of inheritance of the disorder, the number of counselling sessions, the relative workload demand in comparison to disorders for which DNA probe testing is not available, and the geographical distribution of patients referred to the centre.

\section{Methods}

All patients attending the clinics, whether known to the centre or newly referred, were included in the study. In Manchester, in addition to all referrals to St Mary's Hospital, we obtained information on families referred for cystic fibrosis to the Royal Manchester Children's Hospital. Files activated by patient contact by the centre in connection with disease specific registers were also included in the study. Fieldworkers extracted information from clinical notes onto a specially designed form. Approximately $85 \%$ of all new and old referrals seen between August 1986 and July 1987 were included. Information on clinical activity was obtained from family notes kept in the centres. Information kept in other systems was not collected as the main aim of the study was to assess the use of recombinant technology as part of clinical practice. At the beginning of the first year of data collection relatively few notes contained DNA probe results, but there was a marked increase by the end of the year. The amount of DNA work related to clinical activity will be more fully appraised in the second year of observation, which includes a follow up of families with Mendelian disorders who entered the study in the first year.

Data on clinical activity were recorded on a form that was divided into two parts: family summary information and individual patient information. Family data included date of first contact, the initial and final diagnosis (so far), number of family members contacted and counselled, number of DNA samples obtained, visits to the centre or to family's home in the last two years, and number of persons tested. Details for each patient who contacted the centre were obtained for sex, date of birth, position in the pedigree, whether affected or carrier, date of referral, source of referral, changes in carrier risk using only pedigree data, pedigree data and any other test result, and combined risk including DNA probe testing, and household postal code for geographical and socioeconomic distribution of referrals. Results are given according to the mode of inheritance (autosomal dominant, autosomal recessive, $X$ linked, and 'others') or according to the most common disorders for which DNA probes have been used in the genetic centres: Huntington's chorea (HC), myotonic dystrophy (MD), adult polycystic kidney disease (APKD), cystic fibrosis (CF), haemophilia A (HA), and Duchenne or Becker muscular dystrophy (DMD or BMD).

The first approach gives an overview of the potential of recombinant DNA technology in relation to monogenic disorders. Within this, the 'others' include chromosomal, polygenic, and mainly environmental disorders or subjects or families at risk. We have also added to this subgroup disorders for which there is inconclusive evidence that the mode of inheritance is monogenic, according to McKusick. ${ }^{1}$ On most occasions, fieldworkers obtained estimates of the patient's risks from the notes. However, in cases where only a more complex type of risk was given, for example, a combined risk, the other risk estimates were calculated from a set of instructions obtained from the genetic centres. In practice, the most difficult risk calculation was for DMD and BMD where a large proportion of cases are the result of new mutations. For $\mathrm{HC}$ and $\mathrm{MD}$ tables to estimate the risk of being a carrier, given that the subject was free of characteristic symptoms or signs of the disease, were used. Estimates of the empirical risk of Down's syndrome given the mother's age at pregnancy were also calculated.

For assessing the current levels of disability, separate schemes were used for adults and children. For adults, the level of mental disability was categorised according to the need for supervision and ability to be trained to do a single job. Physical disability was assessed according to an adult's ability to dress him/herself. For children, developmental delay was calculated as a ratio of current to expected level of motor and mental development for age. Mild disability was defined as between 11 to $32 \%$ delay, intermediate between 33 to $66 \%$ delay, and severe greater than $67 \%$ delay.

We assessed the distribution of demand according to 'A Classification of Residential Neighbourhood (ACORN)', ${ }^{2}$ District Health Authority (DHA), and Regional Health Authority (RHA) of households according to postal code. The ACORN classification should provide a first impression as to whether referrals to the centre are similarly distributed in all social groups in the community, whereas DHA and 
RHA distributions would give the geographical pattern of referrals in the three centres in the study.

\section{Results}

FAMILY INFORMATION

Information was obtained from 2862 families, of which 2096 were new referrals. Referral according to mode of inheritance followed a similar pattern in Manchester and Cardiff, except that for new referrals there were more autosomal recessive families in Manchester than in Cardiff. In London there were relatively more referred $\mathrm{X}$ linked disorders than elsewhere (table 1). Table 2 gives the number of families contacted for monogenic conditions, for which at least 10 families with the same diagnosis (as classified by McKusick ${ }^{1}$ ) attended any of the three genetic centres, and estimated incidences. Whether the disorder has been mapped and whether DNA probes for assessing carrier risk are available is also indicated. Most of the conditions are of relatively high incidence in comparison to other single gene conditions and for the great majority DNA probes are available. There were, however, other conditions for which demand was low or non-existent despite the relatively high incidence, for example, spherocytosis, familial hypercholesterolaemia, diaphysial aclasia, $\alpha_{1}$ antitrypsin deficiency, congenital adrenal hyperplasia, and ichthyosis. There were other conditions for which there were between five and nine families referred and for which DNA probes are available, for example, aniridia, osteogenesis imperfecta, polyposis coli, familial spastic paraplegia, phenylketonuria, and thalassaemia.

Table 3 shows for each mode of inheritance the number of families and their distribution according to whether any member has provided a sample or been tested with DNA probes. Greater activity was related to $\mathrm{X}$ linked disorders than the other types of inheritance. This was mainly because of DMD and BMD, but also haemophilia A (HA), ornithine transcarbamylase deficiency (OTD), and agammaglobulinaemia. Samples for autosomal recessive (AR) disorders were almost completely restricted to

TABLE 1 Distribution of referrals by mode of inheritance and centre.

\begin{tabular}{|c|c|c|c|c|c|c|c|c|c|c|}
\hline \multirow[t]{2}{*}{ Centre } & \multicolumn{5}{|c|}{ Old referrals } & \multicolumn{5}{|c|}{ New referrals } \\
\hline & $\begin{array}{l}\text { Autosomal } \\
\text { dominant } \\
(\%)\end{array}$ & $\begin{array}{l}\text { Autosomal } \\
\text { recessive } \\
(\%)\end{array}$ & $\begin{array}{l}X \text { linked } \\
(\%)\end{array}$ & $\begin{array}{l}\text { Others } \\
(\%)\end{array}$ & No & $\begin{array}{l}\text { Autosomal } \\
\text { dominant } \\
(\%)\end{array}$ & $\begin{array}{l}\text { Autosomal } \\
\text { recessive } \\
(\%)\end{array}$ & $\begin{array}{l}X \text { linked } \\
(\%)\end{array}$ & $\begin{array}{l}\text { Others } \\
(\%)\end{array}$ & No \\
\hline $\begin{array}{l}\text { Cardiff } \\
\text { London } \\
\text { Manchester } \\
\text { Total }\end{array}$ & $\begin{array}{l}48 \cdot 0 \\
21 \cdot 8 \\
47 \cdot 8\end{array}$ & $\begin{array}{r}7 \cdot 9 \\
12 \cdot 2 \\
10 \cdot 3\end{array}$ & $\begin{array}{l}30 \cdot 6 \\
41 \cdot 0 \\
28 \cdot 6\end{array}$ & $\begin{array}{l}13 \cdot 5 \\
25 \cdot 0 \\
13 \cdot 3\end{array}$ & $\begin{array}{l}229 \\
188 \\
339 \\
756\end{array}$ & $\begin{array}{l}20 \cdot 9 \\
21 \cdot 8 \\
19 \cdot 0\end{array}$ & $\begin{array}{r}8 \cdot 3 \\
23 \cdot 0 \\
21 \cdot 8\end{array}$ & $\begin{array}{r}7 \cdot 3 \\
17 \cdot 2 \\
6 \cdot 6\end{array}$ & $\begin{array}{l}63 \cdot 5 \\
37 \cdot 9 \\
52 \cdot 5\end{array}$ & $\begin{array}{r}731 \\
609 \\
756 \\
2096\end{array}$ \\
\hline
\end{tabular}

TABLE 2 Single gene disorders for which 10 or more families were contacted by incidence and recombinant DNA technology status.

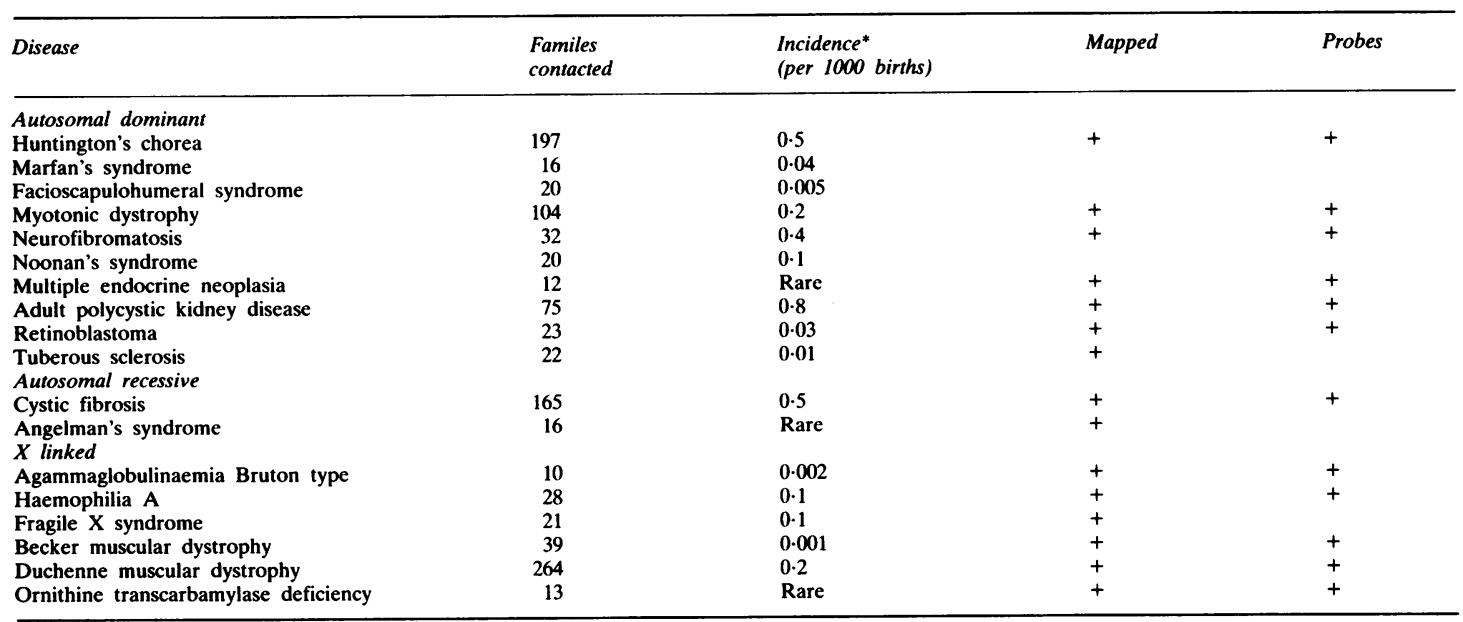

*Incidence from Bergsma, ${ }^{3}$ Carter, ${ }^{4}$ and Weatherall. ${ }^{5}$ 
TABLE 3 Number of families for which at least one family member has provided a sample for DNA testing by mode of inheritance.

\begin{tabular}{|c|c|c|c|c|c|c|c|c|}
\hline & \multicolumn{4}{|c|}{ Old referrals } & \multicolumn{4}{|c|}{ New referrals } \\
\hline & $\begin{array}{l}\text { Not } \\
\text { obtained } \\
(\%)\end{array}$ & $\begin{array}{l}\text { Sample } \\
\text { available } \\
(\%)\end{array}$ & $\begin{array}{l}\text { Sample } \\
\text { tested } \\
(\%)\end{array}$ & No & $\begin{array}{l}\text { Not } \\
\text { obtained } \\
(\%)\end{array}$ & $\begin{array}{l}\text { Sample } \\
\text { available } \\
(\%)\end{array}$ & $\begin{array}{l}\text { Sample } \\
\text { tested } \\
(\%)\end{array}$ & No \\
\hline Autosomal dominant & $42 \cdot 8$ & $46 \cdot 0$ & $11 \cdot 2$ & 313 & $76 \cdot 2$ & $21 \cdot 4$ & $2 \cdot 3$ & 430 \\
\hline Autosomal recessive & $76 \cdot 4$ & $9 \cdot 2$ & $18 \cdot 4$ & 76 & $66 \cdot 4$ & $18 \cdot 0$ & $15 \cdot 6$ & 366 \\
\hline $\mathrm{X}$ linked & $19 \cdot 3$ & $38 \cdot 5$ & $42 \cdot 2$ & 244 & $41 \cdot 8$ & $45 \cdot 7$ & $12 \cdot 5$ & 208 \\
\hline Total & & & & 756 & & & & 2096 \\
\hline
\end{tabular}

cystic fibrosis (CF) while for autosomal dominant (AD) disorders samples for DNA testing were obtained for a large number of disorders. For HC, DNA probe reports were rarely available, possibly for reasons related to ethical issues, while for APKD testing started at the end of the first year's data collection. Among the common disorders (HC, CF, and DMD) the referral pattern was similar in the three centres. For a number of disorders different levels of interest in each of the centres was apparent. In Manchester, a special interest has been developed in relation to APKD and polyposis coli, in Cardiff for myotonic dystrophy (MD) and facioscapulohumeral (FSH) disease, and in London for Angelman's disease, agammaglobulinaemia of Bruton type, HA, and OTD.

Table 4 shows the number of family members contacting the centre according to mode of inheritance. In AR diseases the nuclear family is the focus of activity for the genetic centres, while for $\mathrm{AD}$ and $\mathrm{XL}$ diseases activity is spread over a large number of persons. Table 5 shows the number of persons in contact with the genetic centres for each of the six most common disorders for which DNA probe testing is available. For $\mathrm{CF}$ and $\mathrm{HA}$ relatively few members of each family were contacted. For HA this characteristic may reflect collaborative arrangements between a genetic centre and a department of haematology. For CF this is related to the mode of inheritance of the disease.

The number of family members counselled according to mode of inheritance is shown in table 6 .

TABLE 4 Distribution of families by number of family members contacted and mode of inheritance.

\begin{tabular}{lcrrrr}
\hline & $\begin{array}{l}1-3 \\
(\%)\end{array}$ & $\begin{array}{c}4-6 \\
(\%)\end{array}$ & $\begin{array}{l}7-9 \\
(\%)\end{array}$ & $\begin{array}{l}10 \text { or more } \\
(\%)\end{array}$ & $\begin{array}{l}\text { Total } \\
\text { No }\end{array}$ \\
& & $(\%)$ \\
\hline Autosomal dominant & $56 \cdot 9$ & $25 \cdot 2$ & $7 \cdot 9$ & $10 \cdot 1$ & $741(100)$ \\
Autosomal recessive & $78 \cdot 3$ & $20 \cdot 4$ & 0.9 & $0 \cdot 2$ & $441(100)$ \\
X linked & $32 \cdot 5$ & $36 \cdot 3$ & $16 \cdot 6$ & $13 \cdot 9$ & $451(100)$ \\
Others & $94 \cdot 8$ & $4 \cdot 6$ & $0 \cdot 2$ & $0 \cdot 3$ & $1212(100)$ \\
\hline
\end{tabular}

Counselling in this report is taken as any contact between a family member and clinical staff for any reason other than to provide a specimen for testing and may have taken place at home or at the centre. Obviously, more counselling encounters will be seen in 'old' families than in newly referred families so they need to be recorded separately. In both new and old referred families more counselling encounters occurred in $\mathrm{AD}$ and $\mathrm{XL}$ diseases than other genetic diseases. Among the high frequency diseases for which DNA testing is available, $\mathrm{HC}, \mathrm{MD}$, and APKD had a high number of counselling events.

The number of centre or home visits was ascertained according to mode of inheritance and whether samples for DNA probe testing were collected (table 7). Excluding the group who had no visits to the centre (as this corresponds to families managed elsewhere), there were more visits for families from whom DNA samples were available for AD and XL diseases. This was observed in old and new referrals for centre and homes visits. For AR disorders differences by availability of samples for DNA probe testing were inconsistent.

Table 8 gives the number of subjects tested with DNA probes in each family by mode of inheritance. There were more subjects tested in families with XL disorders and a sizeable number tested in AR

TABLE 5 Numbers of subjects contacted for most common disorders for which DNA probes are available.

\begin{tabular}{|c|c|c|c|c|c|}
\hline & \multicolumn{5}{|c|}{ No of family members contacted } \\
\hline & $\begin{array}{l}1-3 \\
(\%)\end{array}$ & $\begin{array}{l}40 \\
(\%)\end{array}$ & $\begin{array}{l}7-9 \\
(\%)\end{array}$ & $\begin{array}{l}10 \text { or more } \\
(\%)\end{array}$ & No $(\%)$ \\
\hline Huntington's chorea & $42 \cdot 1$ & $23 \cdot 4$ & $11 \cdot 7$ & $22 \cdot 8$ & $197(100)$ \\
\hline Myotonic dystrophy & $24 \cdot 1$ & $38 \cdot 9$ & $21 \cdot 8$ & $15 \cdot 2$ & $104(100)$ \\
\hline kidney disease & $40 \cdot 0$ & $37 \cdot 3$ & $13 \cdot 3$ & $9 \cdot 3$ & $75(100)$ \\
\hline Cystic fibrosis & $69 \cdot 1$ & 29.1 & $4 \cdot 2$ & - & $164(100)$ \\
\hline $\begin{array}{l}\text { Duchenne or Becker } \\
\text { muscular dystrophy } \\
\text { Haemophilia A }\end{array}$ & $\begin{array}{l}24 \cdot 1 \\
42 \cdot 9\end{array}$ & $\begin{array}{l}38 \cdot 9 \\
50 \cdot 0\end{array}$ & $\begin{array}{r}21.8 \\
3.6\end{array}$ & $\begin{array}{r}15 \cdot 2 \\
3 \cdot 6\end{array}$ & $\begin{array}{r}303(100)) \\
28(100)\end{array}$ \\
\hline
\end{tabular}


TABLE 6 Number of family members counselled for new and old referrals by mode of inheritance.

\begin{tabular}{|c|c|c|c|c|c|c|c|}
\hline & \multicolumn{7}{|c|}{ No counselled } \\
\hline & $\begin{array}{l}0 \\
(\%)\end{array}$ & $\begin{array}{l}1-2 \\
(\%)\end{array}$ & $\begin{array}{l}3-4 \\
(\%)\end{array}$ & $\begin{array}{l}5-6 \\
(\%)\end{array}$ & $\begin{array}{l}7-8 \\
(\%)\end{array}$ & $\begin{array}{l}9 \text { or more } \\
\text { (\%) }\end{array}$ & No $(\%)$ \\
\hline \multicolumn{8}{|l|}{ Old referrals } \\
\hline Autosomal dominant & $7 \cdot 0$ & 33.9 & $23 \cdot 3$ & $14 \cdot 4$ & $5 \cdot 1$ & $16 \cdot 3$ & $313(100)$ \\
\hline Autosomal recessive & 14.5 & $67 \cdot 1$ & $17 \cdot 1$ & $1 \cdot 3$ & - & - & $76(100)$ \\
\hline $\mathrm{X}$ linked & $9 \cdot 8$ & 28.7 & 29.9 & $16 \cdot 4$ & 7.4 & $7 \cdot 8$ & $244(100)$ \\
\hline $\begin{array}{l}\text { Others } \\
\text { New referrals }\end{array}$ & $2 \cdot 4$ & $87 \cdot 8$ & 6.5 & 0.8 & $0 \cdot 8$ & $1 \cdot 6$ & $123(100)$ \\
\hline Autosomal dominant & $18 \cdot 4$ & $63 \cdot 5$ & $12 \cdot 8$ & 2.6 & 1.4 & 1.4 & $430(100)$ \\
\hline Autosomal recessive & $22 \cdot 4$ & $72 \cdot 3$ & 4.4 & 0.3 & - & - & $366(100)$ \\
\hline $\mathrm{X}$ linked & 28.4 & 53.8 & 11.5 & 2.9 & $2 \cdot 4$ & 1.0 & $208(100)$ \\
\hline Others & $6 \cdot 8$ & $90 \cdot 7$ & $2 \cdot 4$ & 0.2 & - & - & $1092(100)$ \\
\hline
\end{tabular}

TABLE 7 Mean number of subjects visiting the centre and home per family in new and old referrals by mode of inheritance and availability of DNA samples.

\begin{tabular}{|c|c|c|c|c|c|c|c|c|}
\hline \multirow[t]{2}{*}{ DNA sample } & \multicolumn{2}{|c|}{ Autosomal dominant } & \multicolumn{2}{|c|}{ Autosomal recessive } & \multicolumn{2}{|l|}{$X$ linked } & \multicolumn{2}{|l|}{ Others } \\
\hline & $\begin{array}{l}\text { Not available } \\
\text { Mean (SD) }\end{array}$ & $\begin{array}{l}\text { Available } \\
\text { Mean (SD) }\end{array}$ & $\begin{array}{l}\text { Not available } \\
\text { Mean (SD) }\end{array}$ & $\begin{array}{l}\text { Available } \\
\text { Mean (SD) }\end{array}$ & $\begin{array}{l}\text { Not available } \\
\text { Mean (SD) }\end{array}$ & $\begin{array}{l}\text { Available } \\
\text { Mean (SD) }\end{array}$ & $\begin{array}{l}\text { Not available } \\
\text { Mean (SD) }\end{array}$ & $\begin{array}{l}\text { Available } \\
\text { Mean (SD) }\end{array}$ \\
\hline $\begin{array}{l}\text { Old referrals } \\
\text { Centre } \\
\text { Home } \\
\text { New referrals } \\
\text { Centre } \\
\text { Home }\end{array}$ & $\begin{array}{l}(n=84) \\
2 \cdot 18(1.26) \\
0.61(0.93) \\
(n=269) \\
1 \cdot 15(0.53) \\
0 \cdot 21(0.45)\end{array}$ & $\begin{array}{l}(n=89) \\
2.62(2.98) \\
2.98(4.81) \\
(n=84) \\
1.71(2.29) \\
0.77(1.29)\end{array}$ & $\begin{array}{l}(n=51) \\
1.88(1.07) \\
0.26(0.63) \\
(n=227) \\
1.14(0.43) \\
0.19(0.45)\end{array}$ & $\begin{array}{l}(n=15) \\
1.47(0.74) \\
0.27(0.59) \\
(n=67) \\
1.31(0.72) \\
0.07(0.26)\end{array}$ & $\begin{array}{l}(n=22) \\
1.68(0.78) \\
0.23(0.53) \\
(n=72) \\
1.23(0.49) \\
0.31(0.53)\end{array}$ & $\begin{array}{l}(n=111) \\
2.03(1.30) \\
1.11(1.91) \\
(n=69) \\
1.74(1.29) \\
0.42(1.02)\end{array}$ & $\begin{array}{l}(n=111) \\
1.94(1.65) \\
0.32(0.75) \\
(n=1030) \\
1.23(0.56) \\
0.25(0.55)\end{array}$ & $\begin{array}{l}(n=2) \\
5.00(1.41) \\
0.50(0.71) \\
(n=8) \\
1.25(0.46) \\
0.50(0.93)\end{array}$ \\
\hline
\end{tabular}

TABLE 8 Distribution of families according to number of subjects DNA tested in a family by mode of inheritance.

\begin{tabular}{llrrll}
\hline $\begin{array}{l}\text { No of subjects } \\
\text { DNA tested }\end{array}$ & $\begin{array}{l}\text { Autosomal } \\
\text { dominant }\end{array}$ & $\begin{array}{l}\text { Autosomal } \\
\text { recessive }\end{array}$ & $X$ linked & Others & Total \\
\hline 0 & 696 & 371 & 323 & 1213 & \\
1 & 17 & 6 & 36 & - & \\
2 & 11 & 23 & 27 & 1 & \\
3 & 6 & 30 & 25 & - & \\
4 & 6 & 5 & 10 & - & \\
5 & 5 & 4 & 12 & - & \\
6 or more & - & 3 & 19 & & 2849 \\
No of families & 741 & 442 & 452 & 1214 & \\
\hline
\end{tabular}

disorders. These results are related to the activity in DMD and CF for XL and AR respectively.

\section{ACTIVITY ASSOCIATED WITH INDIVIDUAL \\ SUBJECTS}

Information on 10185 persons was obtained from the 2852 families in the study. Table 9 gives the distribution of these subjects according to the specialties from which they were referred to the genetic centres restricted to the 20 most frequently reported. Most patients were referred by paediatricians, GPs, obstetricians, and neurologists. Although comparisons based on old and new referrals may be biased, as old referrals are not a random sample of past referrals, there appears to be a marked increase in the number of obstetrician
TABLE 9 Referral pattern by speciality (top 20).

\begin{tabular}{lccr}
\hline Speciality & $\begin{array}{l}\text { Old } \\
\text { referrals }\end{array}$ & $\begin{array}{l}\text { New } \\
\text { referrals }\end{array}$ & Total \\
\hline Paediatrics & 483 & 1064 & 1547 \\
General practitioners & 322 & 600 & 922 \\
Genetics & 262 & 536 & 798 \\
Obstetrics & 94 & 664 & 758 \\
Neurology & 172 & 285 & 457 \\
General medicine & 71 & 70 & 141 \\
Ophthalmology & 34 & 87 & 121 \\
General and orthopaedic surgery & 24 & 54 & 78 \\
Metabolic & 31 & 43 & 74 \\
Gynaecology & 14 & 52 & 66 \\
Child assessment & 8 & 58 & 66 \\
Urology & 31 & 14 & 45 \\
Paediatric surgery & 1 & 37 & 38 \\
Ear, nose, and throat & 4 & 33 & 37 \\
Mental illness & 19 & 17 & 36 \\
Haematology & 11 & 20 & 31 \\
Baby care & 7 & 23 & 30 \\
Dermatology & 7 & 23 & 30 \\
Endocrinology & 1 & 27 & 28 \\
Cardiology & 1 & 26 & 27 \\
Self-referral & 117 & 85 & 203 \\
Health visitor & 19 & 20 & 39 \\
Social worker & 11 & 5 & 16 \\
\hline
\end{tabular}

generated referrals. A relative increase in the number of referrals from other genetic departments was also observed. This may correspond to collaborative arrangements between geneticists in Britain. It is important that any education programme concerned with genetic services should 
reach a wide audience, as a large number of specialities refer a sizeable number of patients to the genetic centres. Of particular interest is the self referred or family referred people. A very large percentage of these ( $50 \%$ of 202 people) contacted the centre in relation to diseases for which DNA probe testing is available. That this may have been generated in part by the new technology is supported by the proportionally large number of subjects diagnosed as DMD and $\mathrm{HC}$ among the old referrals and $C F$ among the new referrals, as this was the order in which DNA testing for these disorders was introduced.

Table 10 gives the distribution of subjects from AD families according to their pedigree risk and age. Age can be used as a proxy measure for the number of subjects who will receive counselling for family planning now and in the next 10 years by carrier risk. Those aged between 16 and 45 years would influence present demand and those below future demand. Approximately one-third of the subjects contacted have carrier risks between 16 and $75 \%$ using pedigree information alone. The majority of those with risks between 0 and $5 \%$ are the spouses of established carriers or subjects with a high risk of being carriers. For AR disorders, most referrals to the centre were obligatory carrier

TABLE 10 Distribution of subjects by their estimated carrier risks based on pedigree assessment for subjects from families with autosomal dominant disorders.

\begin{tabular}{lccccc}
\hline \multicolumn{7}{c}{ Carrier risk } & & & \\
\cline { 2 - 6 } & $0-5 \%$ & $6-15 \%$ & $16-25 \%$ & $26-75 \%$ & $96-100 \%$ \\
\hline 5 or less & 11 & 4 & 27 & 37 & 106 \\
$6-15$ & 25 & 11 & 65 & 96 & 95 \\
$16-25$ & 91 & 10 & 76 & 246 & 164 \\
$26-35$ & 209 & 8 & 41 & 216 & 185 \\
$36-45$ & 148 & 4 & 18 & 131 & 166 \\
$46-55$ & 77 & 2 & 9 & 94 & 158 \\
56 or more & 101 & 3 & 11 & 83 & 136 \\
Not known & 430 & 11 & 34 & 95 & 113 \\
Total & 1092 & 53 & 281 & 998 & 1123 \\
\hline
\end{tabular}

Only one subject was assessed as carrier risk between 76 and $95 \%$ (not included in the table).

TABLE 11 Carrier risk changes between pedigree $(P)$ risk, pedigree and another test except DNA testing (PT) risk, and combined risk including DNA testing (C) for Duchenne or Becker muscular dystrophy in women.

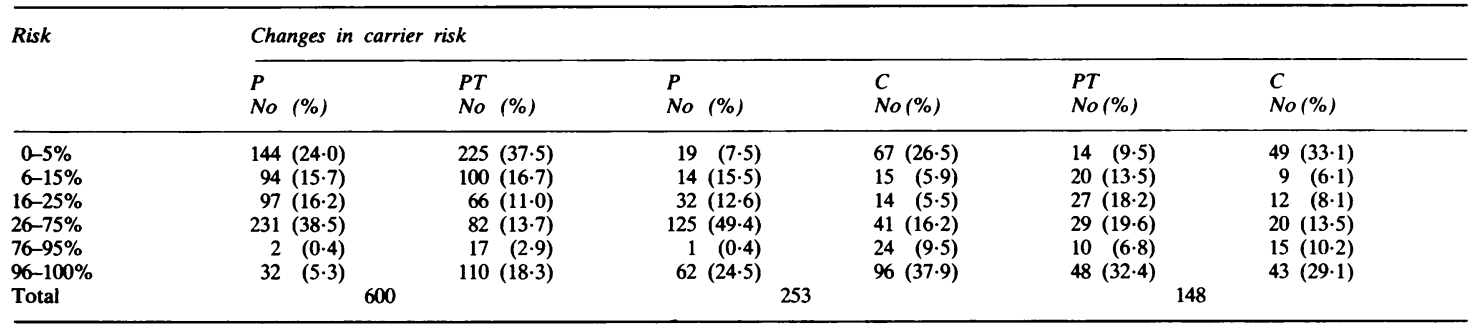

couples. For XL disorders, a large percentage of women (approximately $50 \%$ ) had, based on pedigree only, a carrier risk between 16 and $75 \%$.

The three estimates of risk, pedigree assessment (P), pedigree and any other test excluding DNA probe testing (PT), and combined risk (C) (pedigree, any test, and DNA probe testing), were obtained to assess the effect of tests on risk estimates. One way of measuring the efficacy of a test would be to use the increase in the number of is, $0 \%$ or $100 \%$ risk of being a carrier, or equivalently the decrease in the number of subjects in the intermediate carrier risk groups. As explained in the methods section, the DNA testing process as a service commitment was just starting in the period up to July 1987 . To illustrate the process, table 11 shows changes in risk estimates owing to the use of DNA and non-DNA tests for DMD and BMD, as most subjects studied with DNA probes were from families with these diseases. The changes from $P$ to PT risk, $P$ to $C$ risk, and PT to $C$ risk are shown. There was an increase in the percentage of subjects in the 0 to $5 \%$ and 96 to $100 \%$ risk groups and a corresponding decrease in the intermediate carrier risk groups when any extra information on $\mathbf{P}$ risk was available. The extra information provided by DNA probe testing was associated with an increase in the percentage of subjects in the 0 to $5 \%$ risk group and a decrease in the 16 to $75 \%$ risk groups.

The availability of relatives from three generations is important for preconceptional counselling in AD disorders and table 12 summarises what pedigree structures were available in the three centres for $\mathrm{HC}$. Subjects in the age range 16 to 45 years with a prior risk of $10 \%$ or more by centre were the index cases. Information is shown by genetic centre according to whether a parent or a grandparent was affected. A register of $\mathrm{HC}$ families is available in Manchester and Cardiff. The availability of parental family members was similar in the three centres, but there were more grandparents available for study in subjects at the two ends of the risk distribution, that 
Manchester and Cardiff than in London. However, the percentage with relatives from three generations was low, even in centres keeping a register. A similar finding was observed for MD which has only been actively searched for in Cardiff.

Severity of the conditions referred gives an indication of the cost savings that can be generated from effective preventive measures. This was achieved in the study by collecting data about current sensorial, physical, and mental disability status from the notes, and an assessment of prognosis based on age at which the disease started and its duration was completed according to knowledge about the natural history of the disease. Severe sensorial loss was recorded in 253 out of the 2322 affected family members (severe short sightedness or blindness 158 , severe hearing loss 77 , and severe sensorial loss 18). Sensorial losses were more common in the AR group $(18 \%)$ and the 'others' group $(13 \%)$ than in the AD and XL groups $(8 \%)$.

Table 13 shows for each mode of inheritance the distribution of affected patients according to prognosis in terms of life threat and level of disability. The table illustrates that a very large percentage of affected patients have a poor prognosis in terms of life threat or disability for each type of inheritance.
Only $20 \%$ of the affected patients were given a $\stackrel{\Phi}{=}$ favourable prognosis for their disease. In contrast, $\overrightarrow{\vec{B}}$ $36 \%$ of the affected patients had a very poor prognosis in terms of disability or life threat. Additionally, disorders referred to genetic centres are of long duration regardless of the mode of $\frac{\omega^{\circ}}{\alpha}$ inheritance and therefore are expensive in terms of $a$ medical, social, and educational care.

In the year of study the most frequent laboratory $\overrightarrow{0}$ request was for DNA probe testing. As a proxy $\overrightarrow{ }$ measure of DNA probe testing work, the percen- $\vec{\omega}$ tage of subjects for whom a blood sample for DNA testing was obtained by main diagnosis is shown in table 14. For MD, CF, DMD or BMD, and $\mathrm{HA}$

TABLE 14 Number contacted and percentage of these providing a DNA sample by diagnosis.

\begin{tabular}{lcl}
\hline & $\begin{array}{l}\text { No } \\
\text { contacted }\end{array}$ & $\begin{array}{l}\text { \% sample } \\
\text { available }\end{array}$ \\
\hline Huntington's chorea & 1387 & 27.0 \\
Myotonic dystrophy & 597 & 64.3 \\
Adult polycystic kidney disease & 366 & 17.5 \\
Cystic fibrosis & 521 & 59.9 \\
Duchenne or Becker muscular dystrophy & 1870 & 64.8 \\
Haemophilia A & 102 & 55.9 \\
Others & 5386 & 10.8 \\
\hline
\end{tabular}

TABLE 12 Frequency of pedigree structure in HC risk families contacted for subjects aged 16 to 45 years with prior HC risk of $\geqslant 10 \%$.

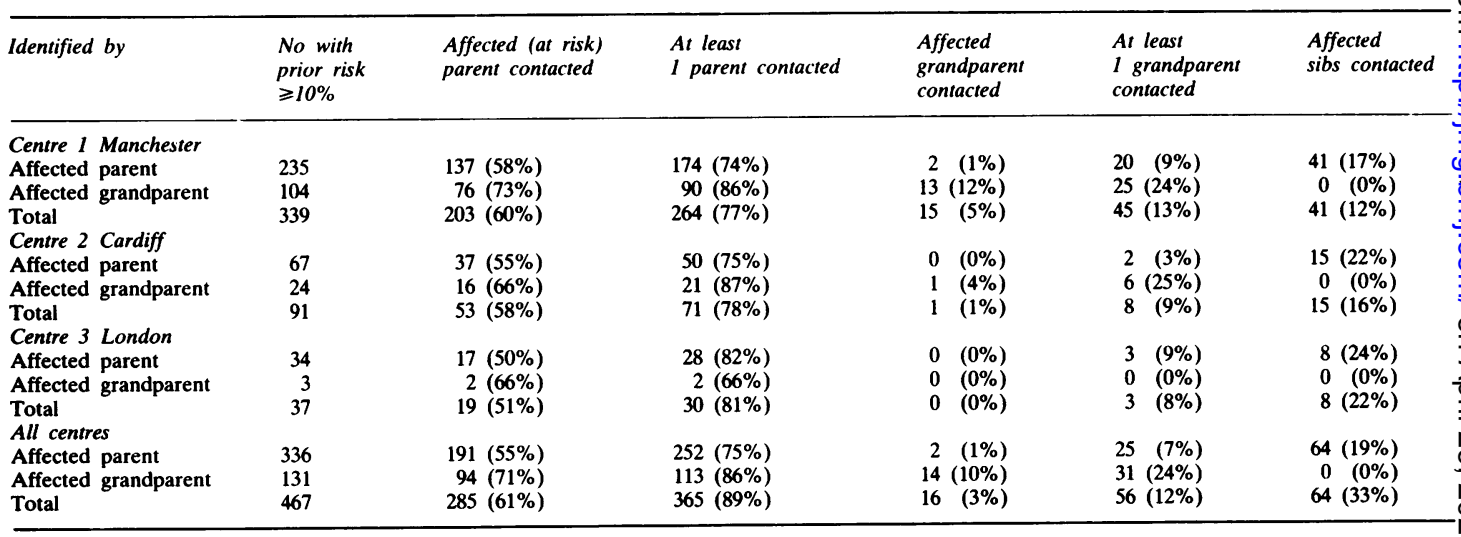

TABLE 13 Distribution of affected patients by mode of inheritance and prognosis.

\begin{tabular}{|c|c|c|c|c|c|c|c|c|c|}
\hline \multirow{2}{*}{$\begin{array}{l}\text { Life threat } \\
\text { Disability }\end{array}$} & \multicolumn{3}{|l|}{ Low } & \multicolumn{3}{|c|}{ Intermediate } & \multicolumn{3}{|l|}{ High } \\
\hline & Low & Intermediate & High & Low & Intermediate & High & Low & Intermediate & High \\
\hline Autosomal dominant & 189 & 202 & 17 & 37 & 394 & 142 & 2 & 8 & 83 \\
\hline Autosomal recessive & 61 & 37 & 9 & 4 & 20 & 38 & - & 4 & 168 \\
\hline $\mathrm{X}$ linked & 26 & 46 & 28 & 9 & 35 & 26 & - & 7 & 203 \\
\hline Others & 194 & 130 & 20 & 12 & 70 & 40 & - & 7 & 27 \\
\hline Total No (\%) & $470(20 \cdot 5)$ & $415(18 \cdot 1)$ & $74(3 \cdot 2)$ & $62(2 \cdot 7)$ & $519(22 \cdot 6)$ & $246(10 \cdot 7)$ & $2(0 \cdot 1)$ & $26(1 \cdot 1)$ & $481(21.0)$ \\
\hline
\end{tabular}


more than $50 \%$ of those contacted gave blood. In Manchester, and to a lesser extent Cardiff, home visiting was the preferred manner of collecting blood specimens. In London most samples were obtained from GPs.

In table 15 the distribution of patients by their Regional Health Authority (RHA) of residence is shown by centre. In Cardiff and Manchester, most referred patients live within the boundaries of the RHA within which the centre is sited $(74 \%$ and $86 \%$ respectively), while only $35 \%$ of referrals in London are resident in the NE Thames Region containing the centre, although $75 \%$ live in London. The different spread of patients according to centre has some effect on the organisation of information in each centre. In Manchester and Cardiff, referrals come from a more defined catchment population than in London and therefore up to date clinical registers are much easier to maintain.

We assessed the referral rates to each centre by obtaining the number of referrals per 1000 population in the DHA. In general, the rates were highest in Manchester and lowest in London with Wales in between. Within each region there were large variations, for example, in Manchester the rates for Chorley, Salford, Bolton, and Blackpool DHA were around 0.5 per 1000 while in central Manchester, south Manchester, Oldham, and Tameside DHAs the rate was on average 1.2 per 1000 . However, these differences may result from limited ascertainment of referrals to the Royal Manchester Children's Hospital from which only families with CF entered the study. More extreme variations were observed in Wales, with west and south Glamorgan DHAs having rates of 1.07 and 1.38 respectively, most other districts with rates between 0.47 and 0.90 , and Clwyd, Gwynedd, and Powys DHAs with rates

TABLE 15 Distribution of patients by centre and regional health authorities (RHAs).

\begin{tabular}{lcccc}
\hline RHAs & Cardiff & London & Manchester & Total \\
\hline Northern & 20 & 15 & 59 & \\
Yorkshire & 24 & 9 & 60 & \\
Trent & 10 & 30 & 69 & \\
East Anglia & 13 & 100 & 1 & \\
Thames North West & 50 & 432 & 3 & \\
Thames North East & 32 & 760 & 1 & \\
Thames South East & 25 & 156 & 3 & \\
Thames South West & 47 & 274 & 2 & \\
Wessex & 23 & 74 & 9 & \\
Oxford & 63 & 102 & 1 & \\
South Western & 62 & 43 & 4 & \\
West Midlands & 101 & 24 & 24 & \\
Mersey & 113 & 5 & 358 & \\
North Western & 8 & 14 & 3196 & \\
Wales & 2010 & 17 & 1 & \\
Scotland & 6 & 12 & 10 & \\
Non-UK & 94 & 106 & 9 & \\
Total & 2701 & 2173 & 3810 & \\
\hline
\end{tabular}

between 0.10 and 0.23 per 1000 . In the London centre the rates between DHAs varied from 0.12 to 0.40 per 1000 .

In general, the distribution of referred subjects by ACORN is similar to that of the general population in England and Wales in 1986. However, there are three exceptions to this description: a deficit of referrals in agricultural households and in households classed as affluent, and an excess of referrals from older terraced housing.

\section{Discussion}

We estimate that between 80 and $85 \%$ of the case notes activated in the year of observation were analysed. A structured form including a family and individual subject's section was used for recording information for those contacting the centre. It is well known that studies based on clinical records not specifically designed for research are not ideal, and this has caused some problems in the study. The first difficulty is that notes are of varied completeness and are not well structured for obtaining the information that the researchers were required to extract. The second is that even when the clinical records are reasonably adequate, some errors in the complex extraction will inevitably occur. These limitations must be remembered when the results are interpreted. However, with the very large amount of information collected, errors of this sort will have little effect on comparisons of groups with respect to frequent events. Comparisons involving relatively rare events should be treated with considerable care until further information is available from subsequent years. For this reason, we have not presented detailed results based on DNA probe testing in pregnancy.

There are two further points relevant to this report. Firstly during the year of observation there were changes in the completeness of DNA probe testing information in the notes. This information was rarely recorded in the notes at the beginning of the year but appeared more frequently towards the end of the year. This in itself is of interest as a reflection of the transition of DNA probe testing from a research and development phase to service use. Secondly, activity not recorded in the notes is lost in this assessment. This may occur for telephone consultations about patients and their families and for patients in hospital for whom a geneticist's opinion was requested but no further contact with the genetic centre was generated. Although relevant, we believe this was a relatively small part of the activity of the genetic centres.

The demand for genetic services will depend on the incidence-prevalence of the disorders, demo- 
graphic trends (number of women in the age band 16 to 45 years and fertility pattern of these women), on traditional patterns of distribution of patients with genetic disorders between geneticists and other specialists, advances in genetic techniques, on professional and lay awareness and beliefs about DNA probes $^{6-9}$ and willingness to use them, and the resolution of ethical issues associated with the use of DNA probes, for example, $\mathrm{HC}^{10}{ }^{10}$ All these factors have influenced the activity of the genetic centres.

Focusing on Mendelian disorders enabled us to document the high number of activated notes for disorders with the highest incidence (HC, neurofibromatosis, MD, APKD, CF, DMD). However, there were interesting exceptions to this; one was in relation to the haemoglobinopathies which can be explained by the existence of the supraregional centre in Oxford dealing with DNA testing for most haemoglobinopathies, and others, such as familial hypercholesterolaemia, otosclerosis, congenital adrenal hyperplasia, and $\alpha_{1}$ antitrypsin deficiency, in which scarcely any activity was detected in the three centres. The lack of activity related to families with hypercholesterolaemia is of particular interest because the disorder is of high frequency ( 2 per 1000 births), DNA probes are available, and the disorder is severe enough to warrant some kind of preventive strategy.

The converse was also observed, that is, disorders of very low incidence but with a relatively high number of family records activated (for example, OTD, agammaglobulinaemia of Bruton type, retinoblastoma). Many of these conditions were part of the activity of one genetic centre. It seems appropriate that for the study of rare diseases using DNA probes cooperative arrangements between all the genetic centres in Britain should be made so that only one or two centres specialise in recombinant DNA technology of rare disorders, especially when the DNA probe testing is complex.

Similar arrangements may also be appropriate for some of the more frequently occurring diseases. For example, there is a very wide distribution of facilities for DNA probe testing for DMD or BMD. All three genetic centres are actively engaged in using DNA probe technology for these patients. Of 10 other genetic centres in England visited by the study team, all but one were using DNA probes in their own laboratory for DMD patients. In one RHA there were three DNA laboratories for the study of these patients. Current methods are intermediate stages to more powerful methods of carrier risk assessment. The backlog of families requiring assessment for DMD and the scientific interest in this disorder may give an overestimate of the regular demand of genetic services. Once this initial stage is over, this condition will generate work $\stackrel{\mathbb{P}}{=}$ related to the incidence of the disease (two cases per $\overrightarrow{\vec{D}}$ 10000 births) and the number of couples receiving DNA probe testing for genetic counselling. This will not justify such a large number of laboratories $\frac{\bar{F}}{\underline{D}}$ dealing with the disease. A system in which a few $\overrightarrow{\mathbb{D}}$ supraregional laboratories were adequately re- $\stackrel{\Omega}{\Omega}$ sourced to provide a high quality service would क probably be the best strategy, especially for dis- $\overrightarrow{0}$ orders for which DNA probe testing is complex. Obviously, for an adequate service, these labora- $\vec{\rho}$ tories would have to deliver results within the required time needed for 'good clinical practice'.

At present the commonest test request in the $\stackrel{\sim}{\sigma}$ genetic centres is for DNA probe testing. This is not only because of the large number of families being studied but also the large number of members within o these families that need to be studied especially for 윽 $\mathrm{AD}$ and $\mathrm{XL}$ disorders.

The DNA probe testing activity will be dependent $\frac{\overrightarrow{ }}{2}$ on the introduction of new probes for disorders for which they were not previously available. This $\vec{\bullet}$ should generate a short span of increased activity as old and newly referred families with the disorder will be initially assessed; however, eventually, for that disorder assessment will be restricted to newly referred families and some members of the old $\bar{D}$ families in relation to family planning. For some $\stackrel{\varnothing}{\varnothing}$ diseases with a complex genetic structure the span of $\unrhd$ high activity will be longer, as some families may be $\overrightarrow{\overrightarrow{0}}$ reassessed with new DNA probes. The testing 3 activity will not only depend on the availability of probes but also on whether treatment for a disorder is available (for example, PKU) or whether the disorder is perceived as less severe (for example, APKD). It is therefore appropriate that centres assess beforehand the extent of interest in DNA testing for specific disorders.

Ethical issues may be difficult to resolve for some disorders like HC. Some centres may be reluctant to 윽 give a diagnosis that would create severe psycholo- $\rightarrow$ gical problems before symptoms become evident. This has been discussed from an ethical viewpoint ${ }^{10-1 i}$ N and from family members' opinions about knowing $ᄋ$ the results of DNA probe testing. ${ }^{6-9}$ Even if ethical $N$ issues were not problematical for some disorders $\underset{\omega}{N}$ (for example, $\mathrm{HC}$ ), predicting carrier risk using DNA probes is impractical because blood from a grandparent has rarely been available up to now, as shown in this report and elsewhere. ${ }^{12}$ However, as $\stackrel{\mathscr{D}}{+}$ data banks and regional services develop three 7 generation blood samples will become more readily available.

The level of awareness of the availability of DNA probes among non-genetic clinicians has not yet $\bar{O}$ been determined. Disorders for which DNA probes 
may be useful can be found in most clinical specialities. The number of self-referred subjects and the very large variation in the referral pattern between RHAs and DHAs within RHAs would suggest that a large proportion of clinicians are not well informed. It appears that some education, possibly by circulating guidelines to non-genetic clinicians about the use of recombinant technology, the type of families that could benefit, and the genetic centres where referrals should be sent, would be an important step forward to maximise the effectiveness of the technology. Since this is almost certain to increase demand, any such educational activity should be devised and implemented by the Departments of Health acting together with all genetic departments in the country.

It is too soon for a definitive appraisal of the effectiveness of the recombinant technology and we will be addressing further aspects of this issue in our study using the second year's data. Nevertheless, a number of findings indicate that this technology is already a useful contribution to clinical practice. Firstly, the technology may be used for a large number of severe disorders for which alternatives are not generally available. Secondly, its preventive effects may entail social and monetary savings for a number of agencies and the family itself. Thirdly, initial assessment confirms the decrease in the percentage of family members in the middle range carrier risk with the use of DNA probes shown in many other studies. ${ }^{13-20}$ However, it is important not to overstate the case. Excluding the haemoglobinopathies, which are studied elsewhere, DNA probes may only prevent a fraction of new cases of the main diseases. This could be for a variety of reasons depending on the disorder, for example, high mutation rates, ethical issues, perceived mildness of the disease or availability of treatment, and the requirement that an affected child be born before an assessment can be made.

From our results, including those on costs not reported here, we have concluded that DNA laboratories are not an expensive development. However, the activity surrounding the collection of information and samples for testing of a large number of family members and the actions related to the consequences of DNA testing involve large staff costs. This will be discussed in more detail in a subsequent publication when the marginal increase in activity related to DNA probes that would require an additional unit of staff will be assessed. Differential costs, for example, between forms of sample collection (when this is not accompanied by other activities like counselling) such as collaboration by GPs instead of home visiting will also need to be assessed. The results so far indicate a very large increase in the number of home visits to families with $\mathrm{AD}$ and $\mathrm{XL}$ disorders associated with DNA probe ascertainment (data not shown).

In conclusion, this assessment of the clinical activity of three genetic centres has clearly identified the use of DNA probe testing as a major and growing element of activity in genetic departments. As long as indirect DNA testing is the predominant manner of using recombinant technology, clinical work related to preconceptional and prenatal carrier risk assessment, affected patients, and counselling will be more important elements of expenditure than DNA laboratories. So far, genetic centres have concentrated on DNA testing for diseases for which there has been a long standing interest. In general this has meant high frequency and severe disorders; however, there are some common disorders which seem to have been excluded from an established pattern of service, for example, familial hypercholesterolaemia. It seems appropriate that the DNA laboratories should be limited. These will need to develop close links with clinical genetics services and the precise structure will need to be established. Clinical genetics services should be organised on a Regional basis. For rare disorders like OTD and common genetic disorders for which an efficacious treatment is available like PKU, one DNA laboratory could deal with the national demand for each specified disease. Even for high frequency disorders of poor prognosis, especially if the gene structure is complex, a relatively few well organised laboratories could deal with the demand. It would certainly be a mistake to allow more DNA laboratories to be developed than are needed to handle the workload.

We are most grateful to Professors $\mathrm{P}$ Harper, R Harris, and M Pembrey, and Dr M Super for commenting on the study documents and giving us access to their centre's clinical and laboratory activity, and Professor W W Holland for his encouragement. We are also indebted to Drs D Donnai, $\mathrm{H}$ Hughes, $\mathrm{H}$ Kingston, and $\mathrm{M}$ Baraitser who provided us with a large percentage of families referred to the centres, Drs R Elles, S Malcolm, $L$ Meredith, and A Read who explained the laboratory aspects of DNA testing, and many others whose advice was much appreciated. The study is funded by the Departments of Health.

\footnotetext{
References

${ }^{1}$ McKusick VA. Mendelian inheritance in men. Catalogs of autosomal dominant, autosomal recessive and $X$-linked phenotypes. 5th ed. Baltimore: Johns Hopkins University Press, 1978.

2 Morgan M. Measuring social inequality: occupational classifications and their alternatives. Community Med 1983;5:116-24.
} 
${ }^{3}$ Bergsma D. Birth defects compendium. 2nd ed. The National Foundation-March of Dimes. London: MacMillan Press, 1979.

4 Carter CO. Monogenic disorders. J Med Genet 1977;14:316-20.

5 Weatherall DJ. The new genetics and clinical practice. 2nd ed. New York: Oxford University Press, 1985.

${ }^{6}$ Evers-Kiebooms G, Cassiman JJ, Van den Berghe H. Attitudes towards predictive testing in Huntington's disease: a recent survey in Belgium. $J$ Med Genet 1987;24:275-9.

${ }^{7}$ Meissen GJ, Berchek RL. Intended use of predictive testing by those at risk for Huntington disease. Am J Med Genet 1987;26: 283-93.

${ }^{8}$ Markel DS, Young AB, Penney JB. At-risk persons' attitudes towards presymptomatic and prenatal testing of Huntington disease in Michigan. Am J Med Genet 1987;26:295-305.

9 Tyler A. Genetic counselling in Huntington's chorea. In: EversKiebooms G, Cassiman JJ, Van den Berghe H, d'Ydewalle G, eds. Genetic risk, risk perception and decision making. March of Dimes-Birth Defects Foundation. New York: Alan R Liss, 1987:85-95.

10 Craufurd DIO, Harris R. Ethics of predictive testing for Huntington's chorea: the need for more information. $\mathrm{Br}$ Med $\mathrm{J}$ 1986;293:249-51.

$"$ King Edward's Hospital Fund. Screening for fetal and genetic abnormality. King's Fund Forum Consensus Statement. London: King Edward's Hospital Fund, 1987.

12 Harper PS. The prevention of Huntington's chorea. The Milroy lecture 1985. J R Coll Physicians Lond 1986;20:7-14.

${ }^{13}$ Cole C, Walker A, Coyne A, et al. Prenatal testing for Duchenne and Becker muscular dystrophy. Lancet 1988;i: 262-6.
14 Darras BT, Harper JF, Francke U. Prenatal diagnosis and detection of carriers with DNA probes in Duchenne muscular dystrophy. N Engl J Med 1987;316:985-92.

15 Forrest SM, Smith TJ, Gross GS, et al. Effective strategy for prenatal prediction of Duchenne and Becker muscular dystrophy. Lancet 1987;ii:1294-7.

16 Hodgson S, Walker A, Cole C, et al. The application of linkage analysis to genetic counselling in families with Duchenne or Becker muscular dystrophy. J Med Genet 1987;24:152-9.

17 Mathy C, Kampmann W, Higuchi M, et al. Cystic fibrosis: typing 48 German families with linked DNA probes. Hum Genet $\vec{O}$ 1987;75:359-61.

18 Meissen GJ, Myers RH, Mastromauro CA, et al. Predictive testing for Huntington's disease with use of a linked DNA o marker. $N$ Engl J Med 1988;318:535-42.

19 Quarrell OWJ, Meredith AL, Tyler A, et al. Exclusion testing for Huntington's disease pregnancy with a closely linked DNA î
marker. Lancet 1987;i:1281-3.

20 Super M, Ivinson A, Schwarz M, et al. Clinic experience of prenatal diagnosis of cystic fibrosis by use of linked DNA N probes. Lancet 1987;ii:782-4.

Correspondence to $\operatorname{Dr}$ R J Rona, Division of Community Health, United Medical and Dental $\overrightarrow{0}$ Schools of Guy's and St Thomas's Hospitals, St Thomas's Campus, London SE1 7EH. 